Original Research Paper

\title{
Prenatal Ethanol Exposure Affects the Proliferation and Differentiation of the Osteoblasts from Newborn Rats
}

\author{
${ }^{1}$ Isabel Chaves Silva Carvalho, ${ }^{1}$ Dennia Perez de Andrade, ${ }^{1}$ Noala Vicensoto Moreira Milhan, \\ ${ }^{1}$ Evelyn Luzia de Souza Santos, ${ }^{2}$ Cristina Pacheco Soares, \\ ${ }^{1}$ Rosilene Fernandes da Rocha and ${ }^{1}$ Luana Marotta Reis de Vasconcellos \\ ${ }^{1}$ Institute of Science and Technology, UNESP-Univ Estadual Paulista, Sao Jose dos Campos (SP), \\ School of Dentistry, Department of Biosciences and Oral Diagnosis, Sao Jose dos Campos, Sao Paulo, Brazil \\ ${ }^{2}$ Institute of Research and Development-IP\&D, Universidade do Vale do Paraiba-UNIVAP, \\ Laboratory Dynamics of Cellular Compartments, Sao Jose dos Campos, Sao Paulo, Brazil
}

Article history

Received: 14-05-2015

Revised: 24-05-2015

Accepted: 16-06-2015

\section{Corresponding Author:}

Isabel Chaves Silva Carvalho

Rua Vicente Klimeika, 78-

Jardim Altos de Sant'anna I

Jacareí-SP-Brasil

Zip-Code: 12306-739,

Tel./Fax: $551239584758 /$

551239479029

Email: belcscarvalho@gmail.com

\begin{abstract}
Alcohol exerts teratogenic effects and its consumption during pregnancy may cause various alterations in the fetus, including deficit of bone development. The objective of this study was to evaluate the initial responses, on osteoblasts isolated from newborn rat calvaria, after prenatal ethanol exposure. Nine pregnant rats were divided into three groups according to the diet fed during pregnancy: Rats fed $20 \%$ ethanol, Pair-fed and control were the groups. At 3 days of life, newborn rats were euthanized for removal of the calvaria and isolation of osteogenic cells by sequential enzymatic digestion. The cells were cultured for a maximum period of 14 days. The effect of alcohol was investigated by the measurement of cell adhesion, proliferation and viability, total protein content, Alkaline Phosphatase (ALP) activity and bone matrix formation. The results showed the highest proliferation in ETH group on the $3^{\text {th }}$ day and the highest ALP activity and bone matrix formation, in this group, on the $14^{\text {th }}$ day, indicating that prenatal ethanol seems to affect the proliferation early and the ALP activity and bone matrix formation in more advanced periods.
\end{abstract}

Keywords: Ethanol, Gestation, Osteoblasts, Rat, Cell Culture

\section{Introduction}

Maternal alcohol consumption during pregnancy can have important teratogenic effects. The direct outcomes for the fetus and newborn include spontaneous abortion, low birth weight, prematurity, asphyxia and perinatal mortality (Moraes and Reichenheim, 2007; Silva et al., 2011) as well as a range of facial and cerebral anomalies, cognitive and growth retardation, neurological and behavioral problems, a group of conditions called "Fetal Alcohol Spectrum Disorders" (FASD) (Barr and Streissguth, 2001).

Some studies in vivo have investigated newborn animals that consumed ethanol before and/or during pregnancy in an attempt to elucidate the mechanisms of action of alcohol on bone tissue of the offspring. Among all the changes that alcohol exposure can cause in fetus and newborn, it has observed delayed ossification, body weight loss, reduced length of individual bones and consequent delay in overall bone growth (Day et al., 1989; Day et al., 2002; Keiver et al., 1997; Keiver et al., 1996; Keiver and Weinberg, 2004; Lee and Leichter, 1980, 1983; Ramadoss et al., 2006; Simpson et al., 2005; Weinberg et al., 1990).

Other studies in vitro have showed the effect of ethanol added directly to the culture medium of different lines of osteoblastic cells (Chavassieux et al., 1993; Friday and Howard, 1991; Gong and Wezeman, 2004; Klein et al., 1996). However, no study evaluated the initial responses on osteoblasts of newborns rats, after prenatal ethanol exposure. Thus, the objective of this study is to investigate the behavior of osteoblast of newborn rats, with respect to basic functions, after prenatal ethanol exposure.

\section{Materials and Methods}

\section{Animals}

All animal procedures were in accordance with the guidelines of the Animal Research Ethics Committee of 
the Sao Jose dos Campos Institute of Science and Technology, Univ Estadual Paulista-UNESP (Protocol No.002/2010 -PA/CEP).

Tree-months-old virgin female Wistar rats, weighing approximately $300 \mathrm{~g}$, were mated and pregnancy was confirmed by vaginal smear as described by (Kato et al., 1979). After the confirmation of pregnancy, the rats were kept in individual cages and divided into three groups that received the following diets daily for the 21 days of pregnancy: The Ethanol group (ETH) was fed 20\% ethanol solution and rodent lab chow ad libitum. The Pair-Fed (PF) group received the same amount of calories as the ETH group. For this purpose, the amount of alcohol and rodent lab chow consumed by animals of the ETH group was measured on the day before and the PF group received the equivalent amount of carbohydrate solution and rodent lab chow on the next day. Control (CONT) animals were fed water and rodent lab chow ad libitum. The $20 \%$ ethanol solution and carbohydrate solution was obtained as previously described by (Marchini et al., 2012). Treatment consisted of oral self-administration of the liquid and solid diets. Rats were maintained in ambient temperature rooms with lights on between $6 \mathrm{~h}$ to $18 \mathrm{~h}$.

The diets were administered for 21 days of gestation. Diet was presented daily and the amount of calories (solid and liquid diet) ingested by animals was measured daily. On the $21^{\text {st }}$ of pregnancy the newborns were born by natural delivery and remained with their mothers until the day of euthanasia. The dams received the diets, liquid and solid, until the day of euthanasia. All newborns were euthanatized at 3 days old for cell isolation.

\section{Cell Isolation and Primary Culture of Osteogenic Cells}

Osteogenic cells were isolated by sequential trypsin/collagenase digestion of calvarial bone obtained from newborn (3 days old). Wistar rats as described previously (Nanci et al., 1996). The pool of cell from each experimental group were plated in 24-well polystyrene plates at a density of 20.000 cells/well. The cells were cultured for a maximum period of 14 days in $\alpha$-Minimum Essential Medium with L-glutamine (Gibco, Invitrogen, Grand Island, NY, USA) supplemented with $10 \%$ fetal bovine serum (Gibco, Invitrogen), $7 \mathrm{mM} \beta$-glycerophosphate (Sigma-Aldrich, St. Louis, MO, USA), $5 \mu \mathrm{g} / \mathrm{mL}$ ascorbic acid (Mallinckrodt Chemicals, Phillipsburg, NJ, UK) and 50 $\mu \mathrm{g} / \mathrm{mL}$ gentamicin (Gibco, Invitrogen) at $37^{\circ} \mathrm{C}$ in a humidified atmosphere with $5 \% \quad \mathrm{CO}_{2}$. The culture medium was changed every 3 days. Progression of the cultures was evaluated by phase contrast microscopy.

\section{Cell Adhesion}

For evaluation of cell adhesion, the cells were cultured for $4 \mathrm{~h}$. The culture medium was removed and the wells were washed three times with Dulbecco's Phosphate Buffered Saline (PBS) (Gibco, Invitrogen) at $37^{\circ} \mathrm{C}$ to eliminate unattached cells. The cells were then enzymatically detached ( $1 \mathrm{mM}$ EDTA, $1.3 \mathrm{mg} / \mathrm{mL}$ collagenase type II and $0.25 \%$ trypsin; Gibco, Invitrogen) and counted in a hemacytometer. Cell adhesion was expressed as the percentage of the initial number of cells (20.000 cells/well).

\section{Cell Proliferation}

For evaluation of cell proliferation, the cells were cultured for 1, 3, 7 and 10 days and enzymatically released from the well by $1 \mathrm{mM}$ EDTA, $1.3 \mathrm{mg} / \mathrm{mL}$ collagenase type II and $0.25 \%$ trypsin (Gibco, Invitrogen). Aliquots of the solutions of each well were incubated for $5 \mathrm{~min}$ with the same volume of $0.4 \%$ Trypan blue (Gibco, Invitrogen), which stains nonviable cells and cells were counted in a hemacytometer. Cell proliferation was expressed as the number of cells per well.

\section{Total Protein Content}

Total protein content was determined using a modification of the method of (Lowry et al., 1951). Briefly, proteins were extracted from each well with $0.1 \%$ sodium lauryl sulphate (Sigma-Aldrich) for $30 \mathrm{~min}$ and mixed 1:1 with Lowry solution (Sigma-Aldrich) for $20 \mathrm{~min}$ at room temperature. The extract was incubated with Folin-Ciocalteau's phenol reagent (Sigma-Aldrich) for $30 \mathrm{~min}$ at room temperature. Absorbance was read in a spectrophotometer (Shimadzu Europa GmbH UV 1203, Duisburg, Germany) at $680 \mathrm{~nm}$. Total protein content was calculated using a standard curve of bovine serum albumin and is expressed as $\mu \mathrm{g} / \mathrm{mL}$.

\section{Alkaline Phosphatase Activity (ALP)}

ALP activity was assayed in the same lysates as used for the determination of total protein content and was measured as the release of thymolphthalein from thymolphthalein monophosphate using a commercial kit (Labtest Diagnóstica, Belo Horizonte, MG, Brazil). Briefly, $50 \mu \mathrm{L}$ thymolphthalein monophosphate was mixed with $0.5 \mathrm{~mL}$ of $0.3 \mathrm{M}$ diethanolamine buffer, $\mathrm{pH}$ 10.1 and left to stand for $2 \mathrm{~min}$ at $37^{\circ} \mathrm{C}$. The solution was then added to $50 \mu \mathrm{L}$ of the lysates obtained from each well and the mixture was incubated for $10 \mathrm{~min}$ at $37^{\circ} \mathrm{C}$. For color development, $2 \mathrm{~mL}$ of a solution of 0.09 $\mathrm{M} \mathrm{Na}_{2} \mathrm{CO}_{3}$ and $0.25 \mathrm{M} \mathrm{NaOH}$ was added. After $30 \mathrm{~min}$, absorbance was read at $590 \mathrm{~nm}$ and ALP activity was calculated from a standard curve using thymolphthalein. The results are expressed as ALP activity normalized for total protein content on days 7, 10 and 14 of culture.

\section{Analysis of the Mineralized Matrix Nodules}

For quantitative analysis of mineralized matrix nodules, the cells were cultured for 14 days. After these periods, the test was carried out according to (Gregory et al., 2004) and (Rosa et al., 2009). After 
the extraction of the dye, the absorbance was measured by spectrophotometer (Biotek-EL808IU) at $405 \mathrm{~nm}$.

\section{Cell Viability}

For assessment of viability, the cells were cultured for 3, 7 and 10 days and then incubated with $100 \mu \mathrm{L}$ of 3-[4,5-dimethylthiazol-2-yl]-2,5-diphenyl tetrazolium bromide $\left(5 \mathrm{mg} \mathrm{mL}^{-1}\right)$ (Sigma-Aldrich), in PBS (Gibco, Invitrogen) for $4 \mathrm{~h}$ at $37^{\circ} \mathrm{C}$. The medium was aspirated and $1 \mathrm{~mL}$ isopropanol acid $(0.04 \mathrm{~N} \mathrm{HCl}$ in isopropanol) (Sigma-Aldrich) was added to each well. The plates were agitated on a plate shaker for $5 \mathrm{~min}$ and $200 \mu \mathrm{L}$ of this solution was transferred to opaque-walled clear-bottom 96-well plates. Optical density was read at 570-650 nm in a plate reader (Biotek EL808IU, Winooski, VT, USA) (De Oliva et al., 2009). The cytotoxicity was expressed as percentage relative to the control group (100\%).

\section{Statistical Analysis}

The results are representative of experiments performed with three distinct primary cultures prepared from the offspring of the animals that composed the groups ( $\mathrm{n}=18$ wells per parameter). These results are reported as the mean \pm standard deviation and a $p$ value $\leq 0.05$ was considered to be statistically significant. Alcohol consumption was analyzed by Kruskal-Wallis and Dunn's tests. Cell adhesion was compared by Student t-test and Mann-Whitney test. Cell proliferation, ALP activity, total protein content and mineralized matrix nodules were analyzed by KruskalWallis and Mann-Whitney tests. Lastly, cell viabiltity was analyzed by $\mathrm{Z}$ test.

\section{Results}

\section{Dam Diet}

The values of solid and liquid diet are compared and described in Tables 1 and 2 (Kruskal-Wallis and Dunn's tests). By analyzing the solid diet, CONT group showed a statistically greater consumption than ETH and PF groups $(\mathrm{p}=<0.0001$ and $\mathrm{p}=<0.0001$, respectively) and ETH group was similar to PF group. According to the liquid diet, CONT group again showed a statistically greater consumption than ETH and PF groups ( $p=0.0004$ and $p=<0.0001$, respectively). However the ETH group showed higher values than PF group $(p=0.0006)$.

Table 1. Analysis comparing solid diet and liquid diet from dams during pregnancy (Kruskal-Wallis test)

\begin{tabular}{llll}
\hline Groups & ETH & PF & CONT \\
\hline Solid diet $(g /$ day/rat) & 12.1 & 12.0 & 19.6 \\
Average & 1.4 & 1.8 & 1.5 \\
Stardard deviation & $<0.0001^{\mathrm{a}}$ & $<0.0001^{\mathrm{a}}$ & $<0.0001^{\mathrm{a}}$ \\
$p$ value & & & \\
Liquid Diet (ml/day/rat) & 28.2 & 13.1 & 41.0 \\
Average & 2.6 & 6.4 & 6.6 \\
Stardard deviation & $<0.0001^{\mathrm{a}}$ & $<0.0001^{\mathrm{a}}$ & $<0.0001^{\mathrm{a}}$ \\
$p$ value & & &
\end{tabular}

${ }^{\mathrm{a}}$ Value considered statistically significant

Table 2. Statistical $p$ values comparing solid diet and liquid diet from dams during pregnancy (Dunn's test)

\begin{tabular}{lll}
\hline Groups & ETH & CONT \\
\hline Solid diet & $<0.0001^{\mathrm{a}}$ & $<0.0001^{\mathrm{a}}$ \\
CONT & $>0,9999$ & \\
PF & & \\
Liquid diet & $0.0004^{\mathrm{a}}$ & $<0.0001^{\mathrm{a}}$ \\
CONT & $0.0006^{\mathrm{a}}$ & \\
PF &
\end{tabular}

${ }^{\mathrm{a}}$ Statistically significant difference

Table 3. Analysis of alcohol consumption

\begin{tabular}{ll}
\hline Alcohol consumption & \\
\hline Average intake of alcohol solution $20 \%(\mathrm{~mL} /$ day/rat) & $28.2 \mathrm{~mL}$ \\
Average intake of absolute alcohol (mL/day/rat) & $5.6 \mathrm{~mL}$ \\
Average intake of absolute alcohol (g/day/rat) & $4.5 \mathrm{~g}$ \\
Feed intake (g/day/rat) & $12.1 \mathrm{~g}$ \\
Feed intake (Kcal/day/rat) & $28.8 \mathrm{Kcal}$ \\
Alcohol consumption $(\mathrm{Kcal} /$ day/rat) & $31.9 \mathrm{Kcal}$ \\
\% Calorie diet from alcohol (average per day/rat) & $52.4 \%$ \\
\hline
\end{tabular}

${ }^{\mathrm{a}}$ Considering that $1 \mathrm{~mL}$ of alcohol is equivalent to $0.790 \mathrm{~g}$

${ }^{\mathrm{b}}$ Considering that $1 \mathrm{~g}$ of commercial food (Labina-Purina ${ }^{\circledR}$, Paulinia, Brazil) has $2.386 \mathrm{Kcal}$

${ }^{\mathrm{c} C}$ Considering that $1 \mathrm{~g}$ of alcohol is equivalent to $7.1 \mathrm{Kcal}$ 


\section{Analysis of Alcohol Consumption}

The average amount of $20 \%$ alcohol solution consumed daily per animal was $28.2 \mathrm{ml}$. With this data it was able to calculate the amount of alcohol consumed in other units of measurement (Table 3). The percentage of calories from the alcohol diet was also calculated. The results showed that on average 52.4\% of dietary calories came from alcohol consumption.

\section{Cell Adhesion}

On the 4th day, a significant difference in the cell adhesion test was observed between the CONT and PF groups $(p=0.016)$. The cell adhesion was higher in the CONT group (Fig. 1). The cell adhesion in ETH group was similar to CONT and PF groups.

\section{Cell Proliferation}

The cell proliferation test showed a significant difference between the groups at 3, 7 and 10 days. On the 3th day, the ETH group presented higher cell proliferation than PF group $(\mathrm{p}=0.005)$, which showed higher values than CONT group $(\mathrm{p}=0.026)$. On the 7 th day ETH group was similar to PF group and both showed higher values than CONT group $(p=0.008$ and $\mathrm{p}=0.048$ ). On the 10th day, the ETH group presented higher cell proliferation than CONT group $(\mathrm{p}=0.004)$. However, ETH group was similar to PF group, which was similar to control group. These results can be observed in Fig. 2.

\section{Total Protein Content}

Total protein content showed a significant difference between the groups only at 7 e 14 days. On the 7 th day, ETH group was similar to PF group and both presented lower values than CONT group $(\mathrm{p}=0.016$ and $\mathrm{p}=0.005)$. On the 14th day ETH group was similar to PF group again and both showed higher total protein content than CONT group $(\mathrm{p}=0.001)$. These results can be observed in Fig. 3 .

\section{Alkaline Phosphatase Activity (ALP)}

The ALP test showed a significant difference between the groups at 7,10 and 14 days. On the 7th and 10th day ETH group was similar to PF group and both $(\mathrm{p}=0.001 ; \mathrm{p}=0.001 ; \mathrm{p}=0.003$ and $\mathrm{p}=0.001)$ presented higher values than CONT group. On the $14^{\text {th }}$ ETH group showed higher ALP than PF and CONT groups ( $p=0.011$ and $p=0.001)$. In this same period, PF group presented higher values than CONT group $(p=0.001)$. These results can be observed in Fig. 4.

\section{Analysis of the Mineralized Matrix Nodules}

The analysis of mineralized matrix nodules showed significant difference between ETH groups to PF ( $p=$ $0.005)$ and CONT group $(p<0.001)$. ETH group presented higher values than $\mathrm{PF}$ and control groups. These results can be observed in Fig. 5 .

\section{Cell Viability}

The data obtained in the MTT test showed that the mean of cell viability in ETH group was above $100 \%$.

When ETH and PF groups were compared to CONT group (100\%), only ETH group showed a significant difference from CONT group, on the 3 th day $(\mathrm{p}<0.001)$. In this period, ETH group presented the highest amount of viable cells (Fig. 6).

When ETH and PF groups were compared between them, there was significant difference $(p=0.002)$. On the 3 th day, ETH group was different from all periods from PF group $(p<0.001)$. On the 7 th day, ETH group was different from $P F$ group on the 3 th day $(\mathrm{p}<0.001)$.

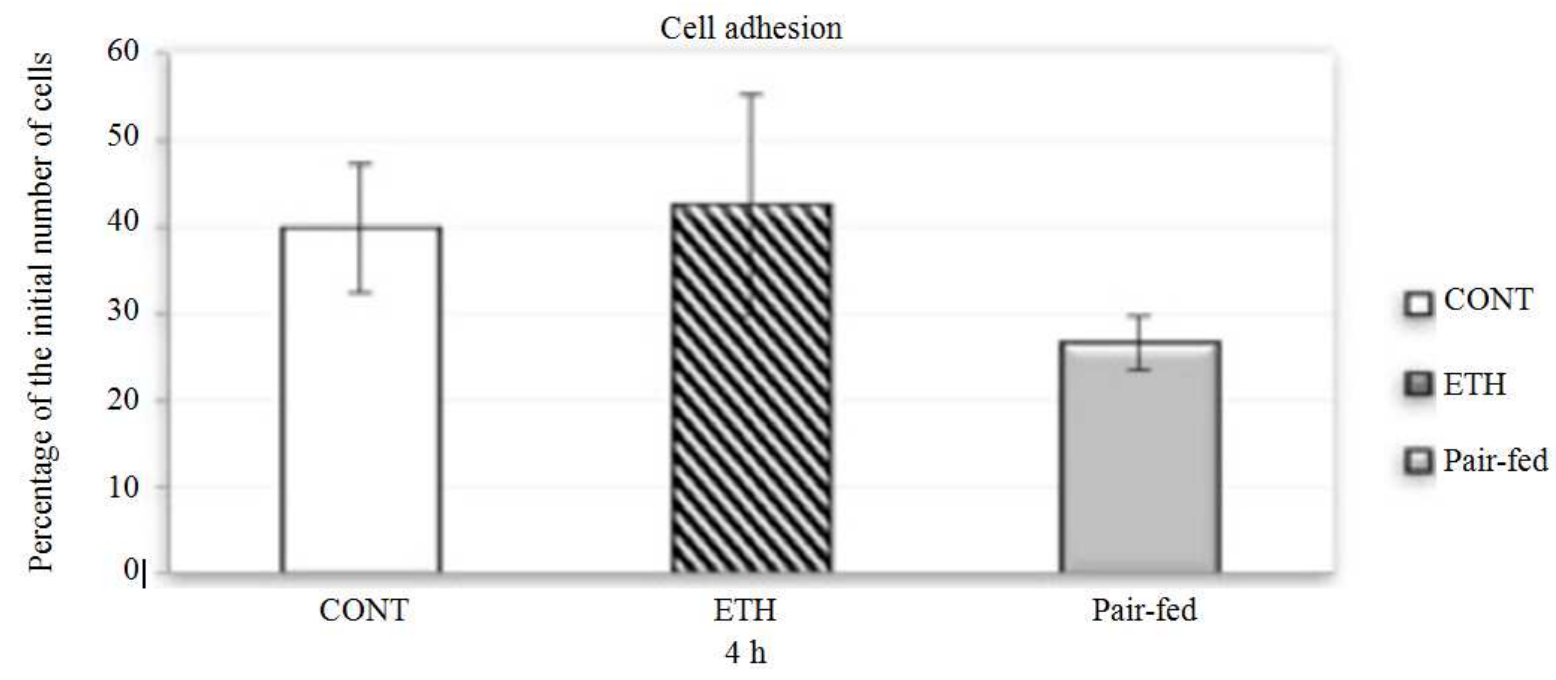

Fig. 1. Graph showing the mean \pm standard deviation percentage of cell adhesion after $4 \mathrm{~h}$ 


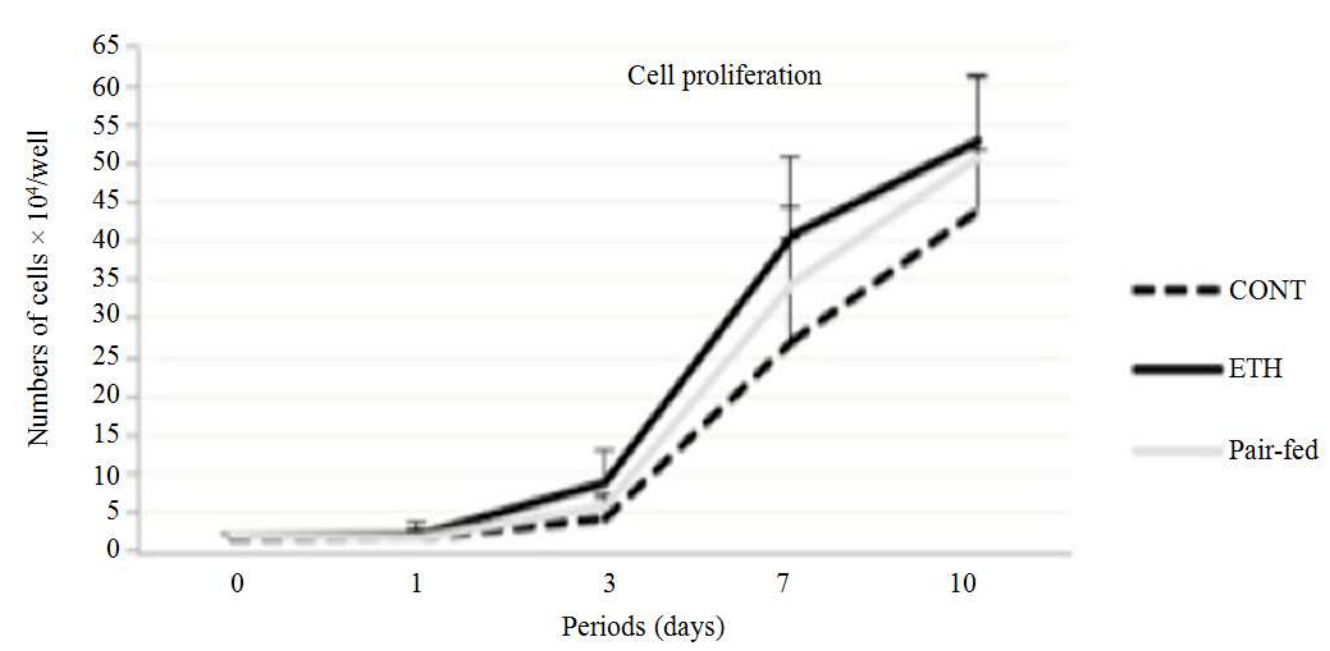

Fig. 2. Graph showing the mean \pm standard deviation of number of cells after 1, 3, 7 and 10 days

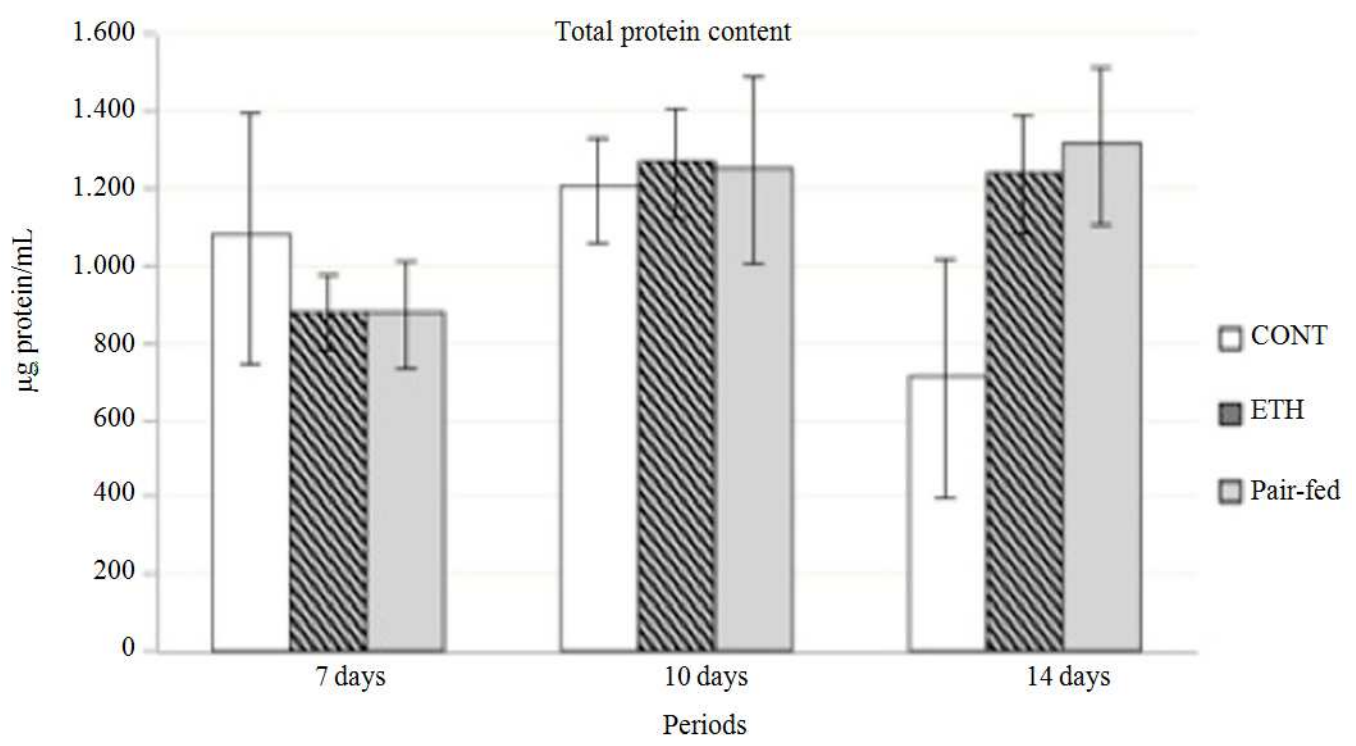

Fig. 3. Showing the mean \pm standard deviation of total protein content in $\mu \mathrm{g} / \mathrm{mL}$, after 7,10 and 14 days

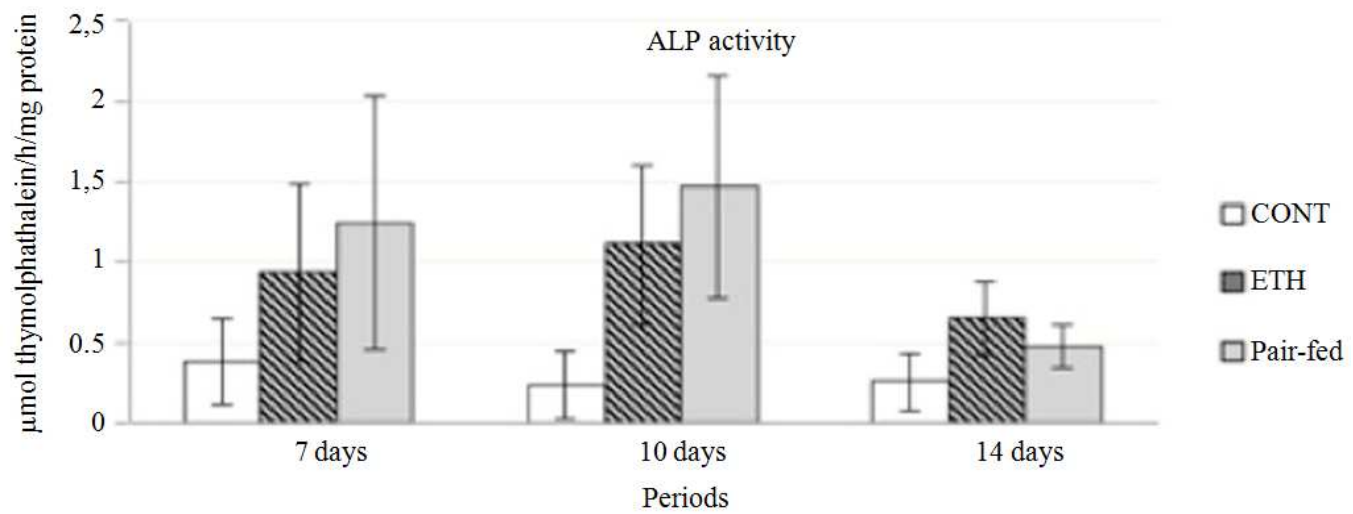

Fig. 4. Showing the mean \pm standard deviation of alkaline phosphatase activity in thymolphthalein micromol/h/mg protein/mL, after 7,10 and 14 days 


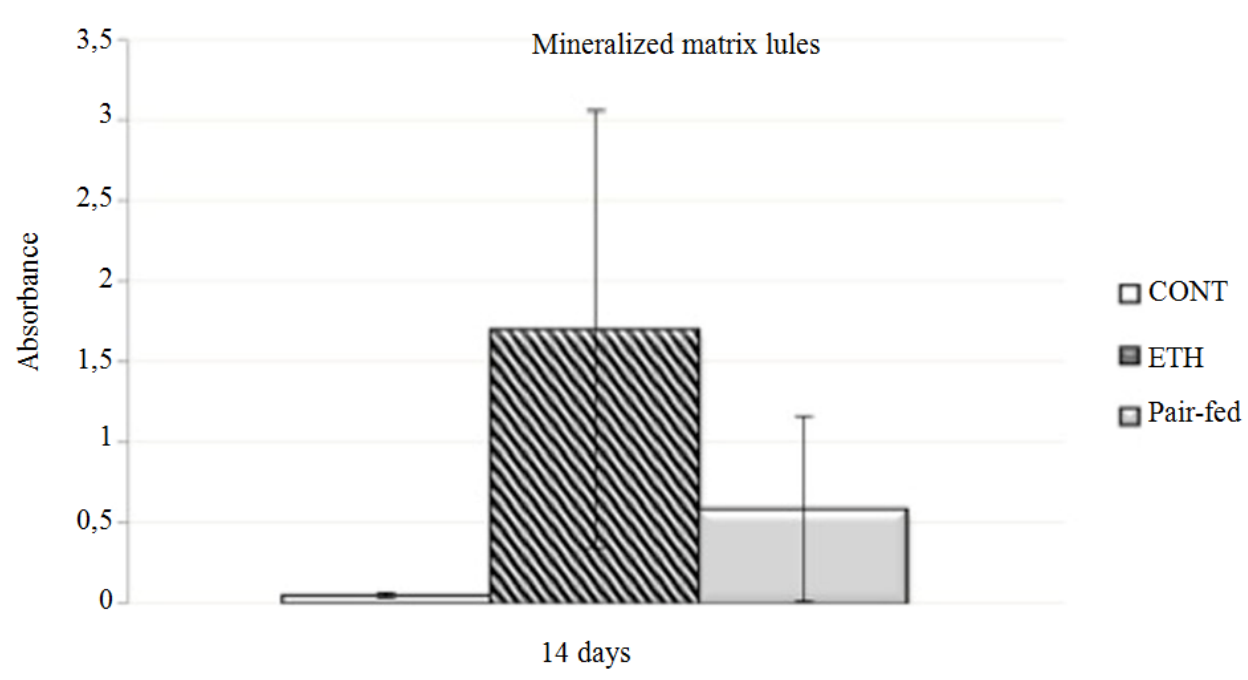

Fig. 5. Showing mean \pm standard deviation of absorbance obtained with analysis of the mineralized matrix nodules after 14 days

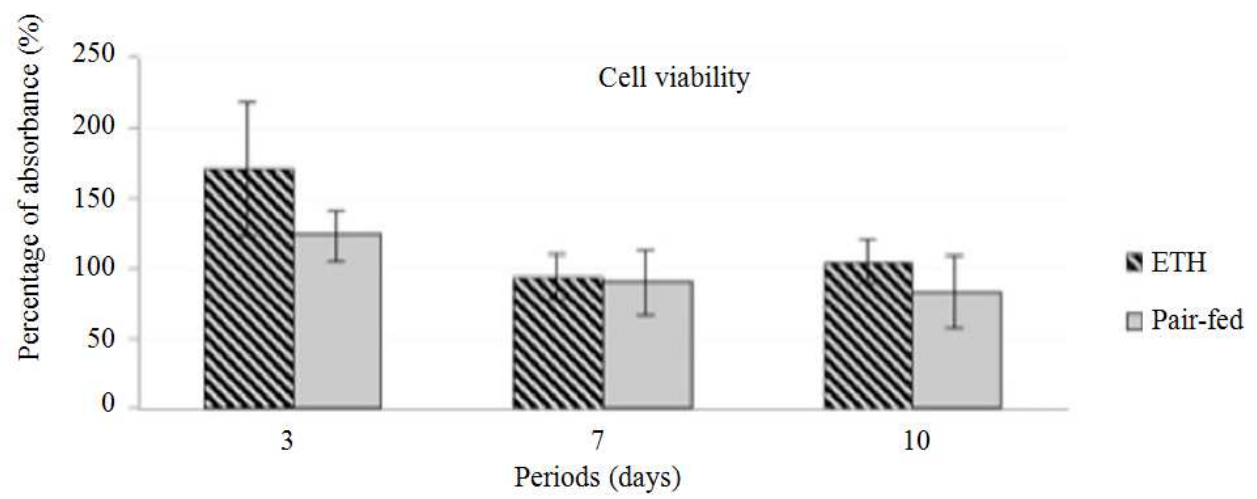

Fig. 6. Graph showing the mean \pm standard deviation percentage of absorbance, obtained with MTT assay, after 3, 7 and 10 days

\section{Discussion}

Studies have indicated that prenatal ethanol exposure affects the skeletal development of the fetus and/or newborn (Day et al., 1989; Day et al., 2002; Keiver and Weinberg, 2004; Lee and Leichter, 1980, 1983; Ramadoss et al., 2006; Simpson et al., 2005; Weinberg et al., 1990) but the mechanisms whereby this occurs are still unclear. In order to investigate these mechanisms, this study was the first that evaluated the initial responses on osteoblasts of newborns rats, after prenatal ethanol exposure.

The average volume of alcohol solution ingested by ETH group was $28.2(\mathrm{ml} /$ day/rat), which corresponded to an average of $52.4 \%$ of total calories came from alcohol. This data suggest that the amount of alcohol consumed by the animals of this study was sufficient for producing alterations in skeletal development of newborns rats, once in other studies $36 \%$ of total calories of the rats came from alcohol and this amount was sufficient to decreased fetal body weight, skeletal ossification concentrations and length of bone (Keiver and Weinberg, 2003, 2004; Simpson et al., 2005).

In addition, the average of cell viability in this study was above $100 \%$ for ETH group. This finding indicates that prenatal ethanol exposure, did not damage the cell viability on osteoblasts of newborns rats.

Due to possible nutritional changes generated by the consumption of alcohol, an isocaloric group was used to establish a nutritional pairing. Thereby, the alterations caused by alcohol, only have considered relevant when EHT group showed a significant difference from PF and CONT groups.

Our results showed that prenatal ethanol exposure improved the proliferation in early stages (on the $3^{\text {th }}$ day) and the ALP activity and bone matrix formation in more advanced periods, at 14 and 21 days, respectively.

The viability was analyzed by MTT assay. Bromide (3-(4,5-dimethylthiazol-2il)-2,5-diphenyl tetrazolium (MTT) test is an assay that shows not only 
the number of cells, but also the level of its metabolic activity because it is based on the activity of enzymes, such as succicil dehydrogenase, which is present in viable cells (Mosmann, 1983).

The cells of ETH group showed higher levels of proliferation than PF and control groups on the $3^{\text {th }}$ day. Moreover, the greatest number of viable cells was seen during this period in ETH group. These results indicate that during this period the ETH group presented higher number of cells than other groups and these cells were viable.

This stimulatory effect in the proliferation of osteoblasts was also observed on cells removed from the femur of rats submitted to chronic alcohol consumption in a previous study (Rosa et al., 2008). On the other hand, some studies have demonstrated an antiproliferative effect of alcohol on osteoblastic cells (Chavassieux et al., 1993; Friday and Howard, 1991; Klein et al., 1996). However, these studies have not evaluated the performance of alcohol systemically because alcohol was added directly to the culture medium of different lines of osteoblastic cells.

The total protein content is associated with the capacity of synthesis of the cells and have been considered a parameter to evaluate the osteogenesis in vitro (Beloti and Rosa, 2005; Rosa and Beloti, 2005). Besides, the production of enzyme alkaline phosphatase is also an indicator of bone formation (Mödder and Khosla, 2008) because this enzyme captures phosphate ions during the process of osteogenesis, being essential to mineralization (Delgado-Calle et al., 2011). When mineralized matrix of bone tissue is observed, the presence of cell differentiation can be confirmed (Hoemann et al., 2009).

Based on the results of this study, prenatal ethanol exposure improves the cell differentiation, promoting an increase in the production of alkaline phosphatase and mineralized bone matrix, on the $14^{\text {th }}$ and $21^{\text {st }}$, respectively. These events are directly correlated, according to previous studies (Beloti and Rosa, 2005; Rosa and Beloti, 2005).

A previous study (Klein et al., 1996) verified an alteration in the ALP synthesis in the ETH group, similar to our study that showed highest levels of ALP in the ETH group in the last period. On the other hand, the reduction in ALP activity in the groups submitted to ethanol was observed in other study that did not evaluate the performance of alcohol systemically (Friday and Howard, 1991). Probably, our findings may provide more accurately support in relation to effects of chronic ethanol consumption on osteoblastic cell differentiation, because our evaluation was systemic.

Rosa et al. (2008) observed a decrease in the mineralized bone matrix when administered alcohol systemically in rats and did ETH exposure of cell cultures. However this author evaluated the stems cells of the rats which were exposed to alcohol, different of our study that showed the responses on osteoblasts of newborns rats, after prenatal ethanol exposure.

Other studies involving more complex cellular mechanisms are needed to clarify why the alcohol enhances the proliferation and differentiation of osteoblasts in some periods and what the relationship of these results with in vivo findings showing that alcohol impairs the ossification.

\section{Conclusion}

Our study was the first that realized prenatal ethanol exposure and verified initial responses on osteoblasts of newborns rats. The ethanol affected the proliferation of these cells early and the ALP activity and bone matrix formation in more advanced periods.

\section{Acknowledgement}

The authors acknowledge support from FAPESP (Fundação de Amparo a Pesquisa do Estado de São Paulo-The State of São Paulo Research Foundation contract grant number 2010/50338-0), CAPES (Coordenação de Aperfeiçoamento de Pessoal de Nivel Superior-Brazilian Federal Agency for Support and Evaluation of Postgraduate Education), native English speaker Kerstin Markendorf and statistician consultant J. Adans.

\section{Funding Information}

This study was funded by the research grant from FAPESP (Fundação de Amparo a Pesquisa do Estado de São Paulo-The State of São Paulo Research Foundation contract grant number 2010/50338-0) and the author Isabel C.S. Carvalho received a scholarship from the Brazilian governamental research agency, CAPES (Coordenação de Aperfeiçoamento de Pessoal de Nivel Superior).

\section{Author's Contributions}

Isabel Chaves Silva Carvalho: Development of research idea, care/treatment of animals, running the experiments, analysis of whole data, writing draft of whole manuscript and final approval of manuscript.

Dennia Perez de Andrade, Noala Vicensoto Moreira Milhan and Evelyn Luzia de Souza Santos: Care / treatment of animals, running the experiments, reading draft, correcting and final approval of manuscript.

Cristina Pacheco Soares: Compiling and analysis of whole data, reading draft, correcting and final approval of manuscript. 
Rosilene Fernandes da Rocha: Project was conceived, planned and coordinated, reading draft, correcting and final approval of manuscript.

Luana Marotta Reis de Vasconcellos: Supervising research work, reading draft, correcting and final approval of manuscript.

\section{Conflict of Interest}

The authors declare that there is no conflict of interests regarding the publication of this paper.

\section{References}

Barr, H.M. and A.P. Streissguth, 2001. Identifying maternal self-reported alcohol use associated with fetal alcohol spectrum disorders. Alcohol. Clin. Exp. Res., 25: 283-287. DOI: $10.1111 / \mathrm{j} .1530-0277.2001 . t b 02210 . \mathrm{x}$

Beloti, M.M. and A.L. Rosa, 2005. Osteoblast differentiation of human bone marrow cells under continuous and discontinuous treatment with dexamethasone. Braz. Dent. J., 16: 156-161. DOI: $10.1590 /$ S0103-64402005000200013

Chavassieux, P., C.M. Serre, P. Vergnaud, P.D. Delmas and P.J. Meunier, 1993. In vitro evaluation of dose-effects of ethanol on human osteoblastic cells. Bone Miner., 22: 95-103. DOI: 10.1016/S0169-6009(08)80221-8

Day, N.L., D. Jasperse, G. Richardson, N. Robles and U. Sambamoorthi et al., 1989. Prenatal exposure to alcohol: Effect on infant growth and morphologic characteristics. Pediatrics, 84: 536-541. PMID: 2771556

Day, N.L., S.L. Leech, G.A. Richardson, M.D. Cornelius and N. Robles et al., 2002. Prenatal alcohol exposure predicts continued deficits in offspring size at 14 years of age. Alcohol. Clin. Exp. Res., 26: 15841591. DOI: 10.1111/j.1530-0277.2002.tb02459.x

Delgado-Calle, J., C. Sañudo, L. Sánchez-Verde, R.J. García-Renedo and J. Arozamena et al., 2011. Epigenetic regulation of alkaline phosphatase in human cells of the osteoblastic lineage. Bone, 49: 830-838. DOI: 10.1016/j.bone.2011.06.006

De Oliva, M.A., W.M. Maximiano, L.M. de Castro, P.E. Jr. de Silva and R.R. Fernandes et al., 2009. Treatment with a growth factor- protein mixture inhibts formation of mineralized nodules in osteogenic cell cultures grown on titanium. J Histochem Cytochem, 57: 265-276. DOI: $10.1369 /$ jhc.2008.952713.

Friday, K.E. and G.A. Howard, 1991. Ethanol inhibits human bone cell proliferation and function in vitro. Metabolism, 40: 562-565.

DOI: 10.1016/0026-0495(91)90044-W
Gong, Z. and F.H. Wezeman, 2004. Inhibitory effect of alcohol on osteogenic differentiation in human bone marrow-derived mesenchymal stem cells. Alcohol. Clin. Exp. Res., 28: 468-479.

DOI: 10.1097/01.ALC.0000118315.58404.C1

Gregory, C.A., W.G. Gunn, A. Peister and D.J. Prockop, 2004. An Alizarin red-based assay of mineralization by adherent cells in culture: Comparison with cetylpyridinium chloride extraction. Anal. Biochem., 329: 77-84.

DOI: $10.1016 /$ j.ab.2004.02.002

Hoemann, C.D., H. El-Gabalawy and M.D. McKee, 2009. In vitro osteogenesis assays: Influence of the primary cell source on alkaline phosphatase activity and mineralization. Pathol. Biol., 57: 318-323.

DOI: $10.1016 /$ j.patbio.2008.06.004

Kato, H., W.K. Morishige and I. Rothchild, 1979. A quantitative relation between the experimentally determined number of conceptuses and corpus luteum activity in the pregnant rat. Endocrinol., 105: 846-850. PMID: 467342

Keiver, K. and J. Weinberg, 2003. Effect of duration of alcohol consumption on calcium and bone metabolism during pregnancy in the rat. Alcohol. Clin. Exp. Res., 27: 1507-1519. DOI: 10.1097/01.ALC.0000086063.71754.C1

Keiver, K. and J. Weinberg, 2004. Effect of duration of maternal alcohol consumption on calcium metabolism and bone in the fetal rat. Alcohol. Clin. Exp. Res., 28: 456-467. DOI: 10.1097/01.ALC.0000118312.38204.C5

Keiver, K., L. Ellis, A. Anzarut and J. Weinberg, 1997. Effect of prenatal ethanol exposure on fetal calcium metabolism. Alcohol. Clin... Exp. Res., 21: $1612-1618$. DOI: $10.1111 /$ j.1530-0277.1997.tb04497.x

Keiver, K., L. Herbert and J. Weinberg, 1996. Effect of maternal ethanol consumption on maternal and fetal calcium metabolism. Alcohol. Clin. Exp. Res., 20: 1305-1312.

DOI: $10.1111 / \mathrm{j} .1530-0277.1996 . t b 01127 . x$

Klein, R.F., K.A. Fausti and A.S. Carlos, 1996. Ethanol inhibits human osteoblastic cell proliferation. Alcohol. Clin. Exp. Res., 20: 572-578. DOI: 10.1111/j.1530-0277.1996.tb01095.x

Lee, M. and J. Leichter, 1980. Effect of litter size on the physical growth and maturation of the offspring of rats given alcohol during gestation. Growth, 44: 327-335. PMID: 7227844

Lee, M. and J. Leichter, 1983. Skeletal development in fetuses of rats consuming alcohol during gestation. Growth, 47: 254-262. PMID: 6642247

Lowry, O.H., N.J. Rosebrough, A.L. Farr and R.J. Randall, 1951. Protein measurement with the Folin phenol reagent. J. Biol. Chem., 193: 265-275. PMID: 14907713 
Marchini, A.M., C.P. Deco, K.B. Lodi, L. Marchini and A.M. Santo et al., 2012. Influence of chronic alcoholism and oestrogen deficiency on the variation of stoichiometry of hydroxyapatite within alveolar bone crest of rats. Arch. Oral Biol., 57:1385-1394. DOI: 10.1016/j.archoralbio.2012.04.011

Mödder, U.I. and S. Khosla, 2008. Skeletal stem/osteoprogenitor cells: Current concepts, alternate hypotheses and relationship to the bone remodeling compartment. J. Cell Biochem., 103: 393-400. DOI: 10.1002/jcb.21423

Moraes, C.L. and M.E. Reichenheim, 2007. Screening for alcohol use by pregnant women of public health care in Rio de Janeiro, Brazil. Rev. Saude Publica., 41: 695-703. DOI: $10.1590 / \mathrm{S} 0034-89102007000500002$

Mosmann, T., 1983. Rapid colorimetric assay for cellular growth and survival: Application to proliferation and cytotoxicity assays. J. Immunol. Methods, 65: 55-63. PMID: 6606682

Nanci, A., S. Zalzal, Y. Gotoh and M.D. McKee, 1996. Ultrastructural characterization and immunolocalization of osteopontin in rat calvarial osteoblast primary cultures. Microsc. Res. Tech., 33: 214-231.

DOI:

$10.1002 /(\mathrm{SICI}) 1097-$ 0029(19960201)33:2<214::AID-JEMT11>3.0.CO;2-X

Ramadoss, J., H.A. Hogan, J.C. Given, J.R. West and T.A. Cudd, 2006. Binge alcohol exposure during all three trimesters alters bone strength and growth in fetal sheep. Alcohol., 38: 185-192. PMID: 16905445
Rosa, A.L. and M.M. Beloti, 2005. Development of the osteoblast phenotype of serial cell subcultures from human bone marrow. Braz. Dent. J., 16: 225-230. DOI: $10.1590 / \mathrm{S} 0103-64402005000300010$

Rosa, A.L., G.E. Crippa, P.T. de Oliveira, M. Taba and L.P. Lefebvre et al., 2009. Human alveolar bone cell proliferation, expression of osteoblastic phenotype and matrix mineralization on porous titanium produced by powder metallurgy. Clin. Oral Implants Res., 20: 472-481.

DOI: 10.1111/j.1600-0501.2008.01662.x

Rosa, M.L., M.M. Beloti, N. Prando, R.H. Queiroz and P.T. de Oliveira et al., 2008. Chronic ethanol intake inhibits in vitro osteogenesis induced by osteoblasts differentiated from stem cells. J. Appl. Toxicol., 28: 205-211. DOI: 10.1002/jat.1271

Silva, I., L.A. Quevedo, R.A. Silva, S.S. Oliveira and R.T. Pinheiro, 2011. Association between alcohol abuse during pregnancy and birth weight. Rev. Saude Publica., 45: 864-869. DOI: $10.1590 / \mathrm{S} 0034-89102011005000062$

Simpson, M.E., S. Duggal and K. Keiver, 2005. Prenatal ethanol exposure has differential effects on fetal growth and skeletal ossification. Bone, 36: 521-532. PMID: 15777686

Weinberg, J., G. D'Alquen and S. Bezio, 1990. Interactive effects of ethanol intake and maternal nutritional status on skeletal development of fetal rats. Alcohol., 7: 383-388. PMID: 2222841 